\title{
The implications of the "USA
}

Patriot Act" and US

counter-terrorism efforts on

international human rights law

by Dr Klint Alexander

\section{INTRODUCTION}

$\mathrm{S}$ ince the tragic events of 11 September 2001, world leaders have voiced more concern over combating terrorism than protecting basic human rights and freedoms. Several nations, including the United States, Great Britain, France, Spain, Japan, Russia, India and Columbia, among others, have established laws that make it easier to arrest, detain and interrogate so-called "suspected" terrorists. Political leaders claim that the enactment of such laws is necessary to effectively carry out the global "war on terrorism." However, an unintended consequence of these new laws has been to legitimize the suppression and mistreatment of non-citizens and minority groups under the pretext of national security.

In the United States, the Bush Administration has invented and marketed a "national security" rationale to justify new legislation and policies aimed at curbing terrorist activity on U.S. soil. The President continuously reminds Americans that $\mathrm{Al}$ Qaeda and nations that harbor terrorists and allegedly possess weapons of mass destruction pose an imminent threat to the United States. As a result, Americans have been galvanized by a renewed sense of patriotism and resolve that has manifested itself in sweeping legislation aimed at protecting national security at the expense of basic human rights. The Uniting and Strengthening America by Providing Appropriate Tools Required to Intercept and Obstruct Terrorism Act of 2001, better known as the "USA Patriot Act," grants the President and the Attorney General significant authority to combat terrorism (The Uniting and Strengthening America by Providing Appropriate Tools Required to Intercept and Obstruct Terrorism Act of 2001 (The "USA Patriot Act”), Pub. L. 107-56, October 26, 2001)).

Under the act, the Justice Department is permitted to set aside the US Constitution to investigate, arrest and detain non-citizens suspected of involvement in "terrorist activity." Moreover, the President has the authority to arrest, detain and punish non-citizens who are suspected of terrorist activity or captured on the battlefield in
America's "war on terrorism" under an Executive Military Order issued in 2001. Previous US administrations engaged in similar tactics of arrest and internment during the American Civil War and World War II under the pretext of national security.

Although it is a principle of warfare that enemy combatants may be detained outside the justice system for the duration of hostilities, such detentions in the United States must comply with internationally recognized standards for the protection of human rights. These standards are embodied and defined principally in the Universal Declaration of Human Rights adopted in 1948 and the International Covenant on Civil and Political Rights of 1966. The purpose of this article is to examine the basic standards set forth in these two treaties and show how the United States has violated its obligations under these treaties in implementing the "USA Patriot Act" and other counter-terrorism measures in its "war on terrorism."

\section{US LEGAL OBLIGATIONS UNDER HUMAN RIGHTS TREATIES}

Following the horror of the Second World War, democratic nations, led by the United States and Great Britain, came together to strengthen democracy and protect minorities by adopting universal standards of humanity, which later came to be known as human rights. The idea of the individual human being as a subject of international law was advanced during the Nuremburg Trials of Nazi war criminals, which set the stage for the establishment of a much broader human rights framework.

In 1945 at the San Francisco conference which established the UN Charter, the governments of the world granted human rights a new international legal status. Article 1 of the UN Charter states that member states must work to "achieve international cooperation . . . in promoting and encouraging respect for human rights and for fundamental freedoms for all without distinction to race, sex, language or religion" (UN Charter art 1). Article 


\section{The Society for Advanced Legal Studies}

\section{PUBLICATIONS}

The funding of terror: the legal implications of the financial war on terror July 2002

Produced by the SALS Interdiction of Terrorist Property Working Group

Price: SALS members $£ 20.00$; non-members $£ 30.00$ + postage (UK free; Europe $£ 5.00$; Rest of World $£ 14.00$ )

\section{The Ethics of Conditional Fee Arrangements}

January 2001

Produced by the SALS Legal Studies, Ethics and Lawyer Fee Arrangements Working Group

Price: SALS members $£ 20.00$; non-members $£ 30.00$ + postage (UK free; Europe $£ 4.00$; Rest of World $£ 12.00$ )

Banking on Corruption: the Legal Responsibilities of Those Who Handle the Proceeds of Corruption

February 2000

Produced by the SALS Anti-Corruption Working Group

Price: SALS members $£ 25.00$; non-members $£ 35.00$ + postage (UK free; Europe $£ 5.00$; Rest of World £14.00)

\section{Parallel Proceedings}

December 1999

Produced by the SALS Financial Regulation Working Group

Price: SALS members $£ 10.00$; non-members $£ 15.00$ + postage (UK free; Europe $£ 2.50$; Rest of World £3.50)

\section{The Cross Border Movement of Children}

November 1999

Produced by the SALS Family Law Working Group

Price: SALS members $£ 15.00$; non-members $£ 25.00$ + postage (UK free; Europe $£ 3.50$; Rest of World $£ 10.00$ )

\section{New Town and Village Greens: Proposals for Law Reform}

December 2002

Produced by the SALS Planning and Environmental Law Reform Working Group

Price: (All purchasers) $£ 10.00+$ postage (UK free; Europe £2.50; Rest of World £4.50)

\section{The Simplification of Planning Legislation}

May 2001

Produced by the SALS Planning and Environmental Law Reform Working Group Price: (All purchasers) $£ 15.00+$ postage (UK free; Europe £2.50; Rest of World £4.50)

\section{Nature Conservation and Habitat Protection - SSSI}

March 1999

Produced by the SALS Planning and Environmental Law Reform Working Group

Price: (All purchasers) $£ 5.00$ + postage (UK free; Europe £2.50; Rest of World £3.50)

An order form for the above reports can be obtained from The Society for Advanced Legal Studies, 17 Russell Square, London WC1B 5DR

(tel: 0207862 5865; fax: 0207862 5855; email: sals@sas.ac.uk), or from our website at: http://ials.sas.ac.uk/SALS/society.htm.

Cheques payable to The Society for Advanced Legal Studies. 
55 provides that the UN will promote "universal respect for, and observance of, human rights and fundamental freedoms" and Article 56 states that members "pledge themselves to take joint and separate action" to achieve that respect.

In 1948, the United Nations General Assembly adopted the Universal Declaration of Human Rights (the "Declaration"), proclaiming: "Everyone is entitled to a social and international order in which the rights and freedoms set forth in this declaration can be fully realized." According to the Declaration, "it is essential, if man is not to be compelled to have recourse, as a last resort, to rebellion against tyranny and oppression, that human rights should be protected by the rule of law" (see Preamble, Universal Declaration of Human Rights, available at http://www.un.org/rights/50/decla.htm.) The Declaration guards against numerous forms of government abuse, including degrading or inhumane treatment (Art 5), discrimination (Art 7), arbitrary arrest and detention (Art 9), detaining individuals without a fair and public hearing (Art 10), and denial of access to counsel (Art 11) or communications with family members (Art 12), among others. The United States is a signatory to the Declaration.

In addition to the Declaration, the United Nations Covenant on Civil and Political Rights details the basic human rights of individuals (see United Nations Covenant on Civil and Political Rights, available at http://www.hrweb.org/legal/cpr.html). Among the rights provided for in the Covenant are the right to presumption of innocence until proven guilty (Art 14(2)), the right to counsel and a speedy trial (Art 14(3)), and the right to privacy (Art 17). The Covenant also forbids inhumane or degrading treatment (Art 7), arbitrary arrest and detention (Art 9), and ensures freedom of movement within one's own country without interference (Art 12). Article 4 of the Covenant permits governments to derogate from these rights in times of "public emergency which threatens the life of the nation" provided that such measures "do not involve discrimination solely on the ground of race, colour, sex, language, religion or social origin." The Covenant became international law in 1976 after being ratified by 35 nations. The United States ratified it in 1992.

The US ratification was conditioned upon the inclusion of certain reservations to ensure consistency within its own Constitution. Specifically, with regard to the Covenant's derogation clause, the United States reserved the right to make distinctions based upon race, colour, sex, language, religion or social origin when such distinctions are "rationally related to a legitimate government objective" (see US Reservations, Understandings, and Declarations, United Nations Covenant on Civil and Political Rights, 138 Cong. Rec. 8068 (1992).

Moreover, with respect to Article 14 - which guarantees a person being detained a right to a speedy and fair hearing, the right to communicate with counsel, and the right to be informed of the charges brought against him - the United States reserved the right to require a detainee to make a showing that any witness whose attendance he seeks to compel is necessary for his defense. These reservations and others provide the United States with more latitude to derogate from the basic provisions than its fellow signatories to the Covenant.

\section{THE "USA PATRIOT ACT" AND OTHER MEASURES TO COMBAT TERRORISM}

In the immediate aftermath of the 11 September tragedy, the Bush administration signed into law the "USA Patriot Act," granting law enforcement officers sweeping new authority to investigate, arrest and detain "suspected" terrorists. Under the act, law enforcement officials have the right to monitor political and religious organizations, to search residential dwellings when no one is home, and to access medical records, bank accounts, store purchases, library readings and e-mails, among other things (see The "USA Patriot Act," Title II). On 30 July 2003, the American Civil Liberties Union and six Muslim groups brought the first constitutional challenge to the act, asserting that the law gives federal agents virtually unchecked authority to spy on Americans (see Eric Lichtblau, "Suit Challenges Constitutionality of Powers in Antiterrorism Law", The New York Times, 31 July 2003, A11). The lawsuit seeks to have the expanded surveillance authority provided for in the act declared unconstitutional on the grounds that it violates the privacy, due process and free speech rights of Americans.

The parts of the Patriot Act which have provoked the most controversy among international human rights activists are sections 411 and 412, which deal with the treatment of aliens. Under these sections, the act allows people, certified by the Attorney General as "terrorists" or to be engaged in other activity that endangers the "national security" of the United States, to be detained without charge for up to seven days, after which they may either be deported or charged and held indefinitely (renewable every six months) if their release is deemed to "threaten the national security of the United States" (see The "USA Patriot Act," $\S \S 411,412$ ). No limitation is placed on the total period of detention and no hearing is permitted on the grounds for the Attorney General's certification. In essence, non-Americans "merely suspected" of being engaged in terrorist activity may be detained arbitrarily and for an indefinite period of time without charge under the act.

The Patriot Act differs in its treatment of American citizens by singling out certain minority groups for protection from discrimination. Section 102 of the act provides for the protection of "civil rights and civil liberties of all Americans, including Arab-Americans, Muslim Americans, and Americans from South Asia." Section 102, however, does not mention non-citizens. Each year, 
millions of non-citizens, including tourists, students, business visitors, trainees, investors and temporary professional workers, arrive for inspection at one of thousands of ports-of-entry across the United States. The act's failure to guarantee non-citizens minimal protection from discrimination leaves them more vulnerable to abuse at international airports, seaports and land-border crossing stations. Thus, the act provides for the protection of US citizens' civil rights, but not the international human rights of non-citizens.

In addition to the enactment of the Patriot Act, President Bush issued a Military Order on 13 November 2003, which allows the President alone the authority to arrest and detain non-citizens who are captured on the battlefield or suspected of involvement in terrorist activity. Specifically, the Order authorizes the detention and trial of non-citizens, whose identities shall be determined from time to time before secret military commissions where the "principles of law and the rules of evidence generally recognized in the trial of criminal cases" do not apply (see Detention, Treatment and Trial of Certain Non-Citizens in the War Against Terrorism, November 13, 2001, § 1(f)).

The maximum penalty permitted to be imposed by the commission is death. Moreover, the Order prohibits the right to appeal in a United States court or international tribunal without the President's approval. Thus, the President has the authority to indict and preside over any appeal, while the President's men sit secretly in judgment of whether a non-citizen is engaged in "terrorist activity," a concept which is not defined in the Military Order.

\section{THE US SOLICITOR GENERAL'S REPORT AND THE IMPACT OF THE "USA PATRIOT ACT” AND COUNTER-TERRORISM EFFORTS ON HUMAN RIGHTS}

The "USA Patriot Act" and the Military Order that followed it have allowed for the arbitrary arrest and detention of nearly 1400 Muslim non-citizens since the 11 September attacks. In each case, there was no presumption of innocence and many of the detainees were subjected to violations of due process, physical and verbal abuse and solitary confinement, among other abuses. Thus far, the Bush administration has refused to provide information on the whereabouts and status of detainees and how the Patriot Act and the President's Military Order were being implemented.

However, in May of 2003, the US Solicitor General released the first report on the Patriot Act disclosing the status and treatment of 762 "suspected terrorists" being held in prisons around the country. According to the report, the Patriot Act has had a substantial adverse impact on basic human rights. Specifically, the report found that immigration laws were being misused under the act to establish a system to detain people indefinitely, sometimes in harsh conditions, rather than charge them. Many of the individuals detained were held in isolation arbitrarily, blindfolded during interrogations, verbally abused, and denied access to lawyers and family members. Attorney General John Ashcroft defended these aggressive arrest and detention tactics on the basis of national security, arguing that such measures were necessary in the war on terror "to protect Americans" (see Adam Liptak, "The Pursuit of Immigrants in America After September 11", The New York Times, 8 June 2003, WK 14).

The report reveals that the Attorney General has failed to capture a single terrorist. After long periods of detention and interrogation, most of the 762 detainees were charged with overstaying their visas or entering the country illegally. None were charged with engaging in or aiding terrorism. Many of those charged with immigration violations have been deported. Not since the era of Joseph McCarthy have so many suspects been rounded up in cities across America and detained against their will without access to counsel or family members.

In addition to the non-citizens who have been arrested and detained in secret under the Patriot Act, approximately 680 Muslim individuals are currently being held without charge at the American Naval Base in Guantanamo Bay, Cuba under President Bush's Military Order. However, unlike the detentions under the Patriot Act, the detentions in Cuba are the result of the arrest and capture of alleged "enemy combatants" in Afghanistan and other countries who are believed to be members of Al Qaeda or engaged in terrorist activities. The Muslim detainees in Cuba are being held in much more secretive and difficult conditions than the detainees in US prisons. Most of the detainees reside in small cages or cells and are blind-folded much of the day. They have been denied access to lawyers as well as prohibited from communicating with family members. Some have requested hearings in US courts, but the Bush administration has denied those requests due to the Order's provision that enemy combatants be tried before secret military commissions. On 9 July 2003, a US federal appeals court upheld President Bush's authority to detain indefinitely enemy combatants captured on the battlefield and to seek the death penalty for those detainees found guilty of having links to terrorism (Neil A. Lewis, "Court Affirms Bush's Power To Detain Citizen As Enemy," The New York Times, 10 July 2003, A17).

The British Government recently expressed its disapproval of the authority of secretive military tribunals to impose the death penalty on detainees at Guantanamo Bay. Of particular concern to the British Government were the fates of two British citizens being held in Cuba as terrorist suspects. The British Government called on the Bush Administration to conduct the secret tribunals with fairness on issues like standards of evidence, the right to counsel, and the right to appeal in case of a guilty verdict and to block the imposition of the death penalty on the British citizens. On 22 July 2003, during a visit by British Prime Minister Tony Blair to Washington, President Bush 
assured the Prime Minister that he will not seek the death penalty for the two Britons being held at Guantanamo Bay (see Sarah Lyall, "Death Penalty Ruled Out For Two British Detainees”, The New York Times, 23 July 2003, A4).

The Guantanamo detentions are in clear violation of US obligations under the Declaration and the Covenant. Articles 5 and 9 of the Declaration specifically guarantee individuals protection from degrading treatment or arbitrary arrest and detention. Moreover, Articles 10, 11 and 12 prohibit the United States from detaining individuals without a public hearing, access to counsel, or communication with family members. The Covenant, too, guarantees each Guantanamo detainee the right to counsel and the right to a speedy trial under Article 14, and it forbids inhumane or degrading treatment and arbitrary arrest and detention under Articles 7 and 9, respectively.

The Bush administration claims that Article 4, the derogation clause, exempts the United States from its obligations under the Covenant because the "war on terrorism" qualifies as a "public emergency which threatens the life of the nation." But such a derogation is only permitted if the measures taken "do not involve discrimination solely on the ground of race, colour, sex, language, religion or social origin."

In the United States, racial discrimination has been at the heart of the US Government's crackdown on terrorism as nearly all of the 1400 detainees under the Patriot Act and the President's Military Order are Muslim noncitizens. Since the 11 September tragedy, racial profiling has intensified in Muslim workplaces, shops, classrooms and mosques across the country. Twice, the Justice Department has directed local law enforcement to conduct so-called "voluntary" interrogations of nearly 8,000 foreigners, mainly Arab or Muslim males ages 18 to 33, residing in the United States. Moreover, under a new federal registration program that is part of the government's counter-terrorism strategy, male noncitizens over the age of 16 from predominantly Muslim countries are required to appear before the immigration authorities and offer proof of their status. Thus, far, approximately 13,000 Muslim individuals have been issued notices to appear before an immigration judge and only a few have been determined to have terrorist ties. These government-endorsed programs are reminiscent of the early treatment of the Jews in Nazi Germany during the 1930s.

\section{THE "PATRIOT II" ACT}

The Patriot Act has sparked official votes of protest from a number of human rights organizations around the world. Amnesty International and the American Civil Liberties Union have criticized the act, including the broad definition of "terrorist activity" for which foreign nationals can be detained or deported. However, the Bush Administration argues that the law does not go far enough and has several weaknesses, which terrorists could exploit.

On 5 June 2003, the US Attorney General urged Congress to give the authorities more power to pursue terrorist suspects by passing new legislation entitled the Domestic Security Enhancement Act of 2003, or "Patriot II" Act (see Eric Lichtblau, "Ashcroft Seeks More Power to Pursue Terror Suspects", The New York Times, 6 June 2003, A1). The proposed law would radically expand law enforcement and intelligence gathering authority by granting officials more power to conduct secret arrests and detentions and to withhold evidence from those being detained. In addition, it would prohibit disclosure of information regarding people detained as terrorist suspects and provide for imposition of the death penalty for new terrorist-related crimes.

Perhaps the most controversial aspect of the "Patriot II" act is that it permits deportation and the stripping of one's citizenship if that individual is found to belong to or support a specific political organization designated by the Attorney General as "terrorist." In defense of the proposed act, Attorney General Ashcroft again applied the "national security" rationale as the reason for seeking expanded authority, stating (in the New York Times article quoted above) that "[w]e must not forget that Al Qaeda's primary terrorist target is the United States of America."

\section{CONCLUSION}

Since the 11 September tragedy, the primary goal of the Bush Administration has been to crack down on terrorism by waging war against rogue nations and arresting and detaining Muslim non-citizens. The enactment of the "USA Patriot Act" and the President's subsequent Military Order have caused the arrest and detention of approximately 1400 Arab and South Asian non-citizens whose basic human rights are being violated under the pretext of "national security" concerns.

The United States is bound by the Universal Declaration on Human Rights and the UN Covenant on Civil and Political Rights to protect non-citizens against various forms of government abuse, including degrading or inhumane treatment, discrimination, arbitrary arrest, indefinite detention, and denial of access to counsel or family members, among others. However, according to a recent report by the US Solicitor General, the Patriot Act and the other counter-terrorism measures implemented by the Bush Administration have had a substantial adverse impact on some of the basic human rights guaranteed under these treaties. Though each treaty provides the United States with flexibility to derogate from its obligations in times of national emergency, the United States is not permitted to violate basic jus cogens norms or discriminate against individuals based on race or religion unless the discrimination passes certain Constitutional requirements. Since the 11 September attacks, the United 
States has failed to comply with its obligations under international law even though the Bush administration continues to defend its tactics on the grounds of national security.

The release of the Inspector General's report was an important development because it provided the first assessment of the Patriot Act and the Bush Administration's counter-terrorism policies since the "war on terrorism" began. Its timeliness also delayed the enactment of the "Patriot II" legislation, which provides the Attorney General with expanded authority to investigate, arrest and detain individuals suspected of involvement in terrorist activities.

It is important for the Bush administration to remember that it needs the cooperation of its allies and the international community to effectively execute its "war on terrorism." The manner in which it is going about it, however, under the Patriot Act and other policies is not endearing itself to those nations that are genuinely concerned about maintaining universal standards of humanity and protecting human rights under international law. (c)

\section{Dr Klint Alexander}

The author is an international lawyer with the law firm of Wyatt, Tarrant \& Combs, LLP in the United States. This paper was presented as part of the Butterworths International Law Seminar series at the Institute of Advanced Legal Studies, University of London, on June 20, 2003.

\title{
Settlement of disputes under the Financial Services and Markets Act 2000 I
}

\author{
by Dr C Chatterjee, Anna Lefcovitch
}

The dispute procedure under the Financial Services and Markets Act 2000 (the "Act") may be found under Part IX (Hearing and Appeals) and Part XVI (The Ombudsman Scheme). The Act has devised a novel system whereby disputes pertaining to matters under the purview of the Act will be settled either through the Ombudsman Scheme or through Part IX procedure under which Part the Financial Services and Markets Tribunal (the "Tribunal") has been set up. It is the purpose of this two-part article to explain he methods of settling disputes that may arise under the provisions of this Act. Although the Ombudsman Scheme has been detailed in Part XVI and not in Part IX, it is thought appropriate to discuss the Ombudsman Scheme first, and thereafter the Tribunal mechanism.

\section{THE OMBUDSMAN SCHEME}

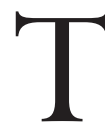

he principal purpose of the Ombudsman Scheme is to provide a mechanism whereby certain disputes may be resolved quickly and with minimum formality by an independent person. It is a compulsory scheme for the resolution of disputes between authorised firms and their customers. This scheme is to be administered by the Scheme operator which must be a body corporate. The Ombudsman Scheme has been detailed in Schedule 17 to the Act. An "Ombudsman" is a person who is a member of the panel, and the panel of Ombudsmen, which is explained below, is detailed in established by the Financial Services Authority (the "FSA"). The Scheme operator must have a chairman, and a board, whose members are a Scheme operator's directors, one of whom must be the chairman. The chairman of the members of the Board must be appointed by the FSA. In the case of the chairman, the approval of the Treasury will be necessary, while on the other hand, paragraph 3 of Schedule 17 provides that the terms of their appointment must be such as to secure their independence from the FSA in the operation of the Scheme.

There must be a panel of ombudsmen which shall enlist persons with appropriate qualifications and experience to 